\title{
USE OF WATERJET IN MANUFACTURING TEST BARS OF High-STRENGTH STEELS
}

\author{
Stepan Jenicek, Kotesovec Vratislav, Tomas Kalina \& Bohuslav Masek
}
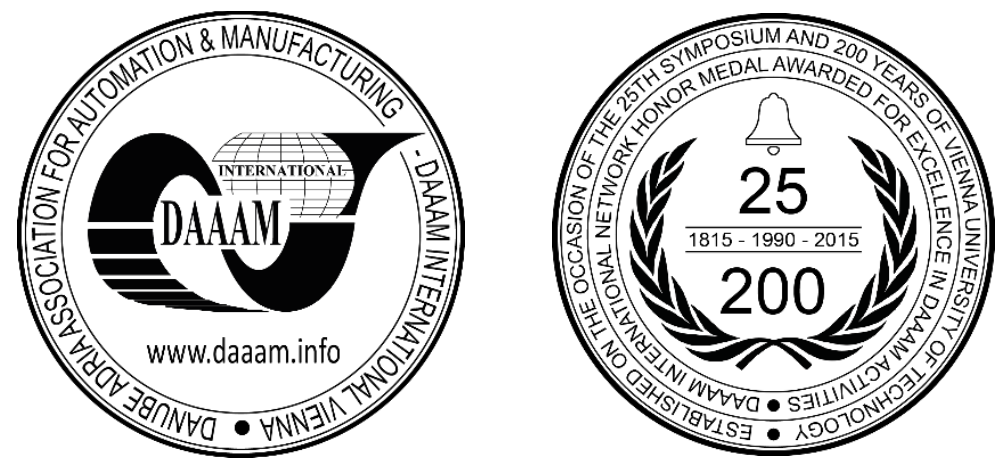

This Publication has to be referred as: Jenicek, S[tepan]; Kotesovec, V[ratislav]; Kalina, T[omas] \& Masek, B[ohuslav] (2016). Use of Waterjet in Manufacturing Test Bars of High-Strength Steels, Proceedings of the 27th DAAAM International Symposium, pp.0219-0224, B. Katalinic (Ed.), Published by DAAAM International, ISBN 978-3-90273408-2, ISSN 1726-9679, Vienna, Austria

DOI: $10.2507 / 27$ th.daaam.proceedings.032

\begin{abstract}
This article introduces a procedure which has been used for developing and optimizing a process of making tensile test specimens of ultra-high-strength sheet metal samples. Thermomechanically-processed materials of this kind are characterized by high hardness, strength, and toughness. Making specimens of these materials by classical chip cutting is therefore difficult, time-consuming, and costly. For the sake of comparison, various methods are listed here which are potential candidates for making such specimens. In this case, an alternative process was chosen: waterjet cutting. From the production viewpoint, the design of the workholding fixture for this process is of major importance. The fixture has an indirect but very significant impact on the manufacturing process and, ultimately, on the quality of the test specimens produced. In this experimental programme, the suitability of the workholding fixture, the process chosen, and the cutting conditions were examined
\end{abstract}

Keywords: Abrasive waterjet cutting; Machining; AWJ; Workholding fixture; AHSS; Unconventional technologies; Test bars.

\section{Introduction}

In order to produce high-quality test specimens from high-strength metal sheets, a new procedure that could deliver the desired quality and effectiveness had to be developed and put in place. Thermomechanically-processed materials of this kind are characterized by high hardness, strength, and toughness [10],[11]. For this reason, making specimens of these materials by classical chip cutting is difficult and costly. Cutting plate is a difficult and time consuming task, especially when the job calls for a tight tolerance or an unusual shape. In those cases, can choose abrasive waterjet cutting [9],[4]. Abrasive waterjet cutting is an attractive process with many advantages. The process is suitable for cutting steel of small thickness where it provides a smooth and very precise cut. In terms of precision, waterjet cutting can even outperform laser cutting, as the resulting edges are smoother and free from melting, burning and thermal distortion [1]. Waterjet is now the most cost effective method to cut steels [9]. Therefore, an alternative machining process of abrasive waterjet cutting was employed. 


\section{Available methods}

Where materials are to be parted or cut, a decision must be made as to the process to be used. Basically, one can choose from four primary cutting processes: oxy-fuel cutting, plasma-arc cutting, laser cutting, waterjet technologies or perhaps wire electrical discharge machining (WEDM). Tensile test specimens must not develop any heat-affected zone during manufacture because in this case the properties imparted by thermomechanical treatment are to be measured. This is the reason why all high-temperature cutting processes [2],[3] have been ruled out, i.e. those which have severe heat effects on the cut area. Hence, the only processes that are still available are waterjet cutting and wire electrical discharge machining.

\subsection{Abrasive waterjet cutting}

Abrasive waterjet is an appropriate choice for cutting any dense materials, ranging from very thin foils to parts of 300 $\mathrm{mm}$ or even greater thickness. Cuts of the highest precision can be made with the aid of draft angle compensation in materials of up to 50-100 mm thickness, depending on the machine design. Rough cuts can be completed in materials much thicker than $100 \mathrm{~mm}$. [4] The process is suitable for cutting steel of small thickness where it provides a smooth and very precise cut. In terms of precision, waterjet cutting can even outperform laser cutting, as the resulting edges are smoother and free from melting, burning and thermal distortion. Waterjet is not constrained by thickness, unlike laser and plasma technologies. Higher costs, on the other hand, are a disadvantage. The investment cost of the equipment exceeds that of plasma cutting equipment while being lower than in laser equipment. By contrast, the operating costs of waterjet cutting are much higher than laser cutting, which is mainly due to the price of the abrasive. [1]

\subsection{Wire electrical discharge machining (WEDM).}

Wire electrical discharge machining can only be used for electrically conductive materials. Sculptured products with a thickness up to $500 \mathrm{~mm}$ can be machined [6]. The greatest advantage of the process is its ability to machine electrically conductive materials regardless of their hardness. The process does not generate any conventional cutting forces. During cutting, only electric erosion forces occur. The cut must be made through thickness of the material. The method is wellsuited for applications that required shape and dimensional accuracy. With the introduction of NC systems, this technology became one of the leading machining processes in terms of precision. The contour accuracy in state-of-theart machines is several micrometres and the quality of the cut surface matches the parameters of ground surfaces. The most common diameter of brass wire used for WEDM is $0.25 \mathrm{~mm}$. Today's top-quality machines can use wires with diameters down to $0.02 \mathrm{~mm}$. Electrical discharge machining does not introduce adverse stresses into the material. It can also produce parts with very thin walls [5]. Nevertheless, the operating costs of WEDM are much higher than those of waterjet, mainly because of its slow machining speed. The investment costs of the equipment are approximately the same as those of waterjet cutting equipment, provided that the cutting space in the machine is considerably smaller.

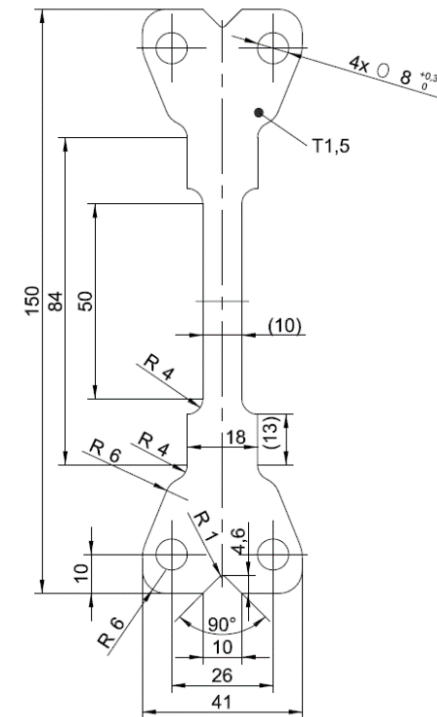

Fig. 1. - Specimen shape

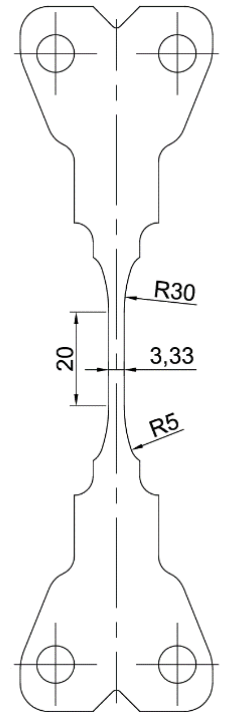

Fig. 2 - Modified specimen shape

\subsection{Process selection}

Optimized test specimens (Fig. 1) are thermomechanically treated in a thermomechanical simulator [7]. They must be converted to standard-shape specimens (Fig. 1) for tensile testing. For reasons related to economy and speed of specimen 
preparation, abrasive waterjet cutting was chosen. For this process, a workholding fixture for accurate and firm clamping of the specimens with respect to the tool had to be designed.

\subsection{Process selection}

The fixture is a very important item, as it has a major impact on the test bar quality. The main reason for using a fixture is the need for quality and dimensional, shape and geometric accuracy.

The requirements for the workholding fixture for waterjet cutting were as follows:

- $\quad$ secure positioning

- firm clamping of the part

- clamping the part in a defined position with respect to the tool

The design (3 and 4) was developed using the SolidEdge ST8 software.

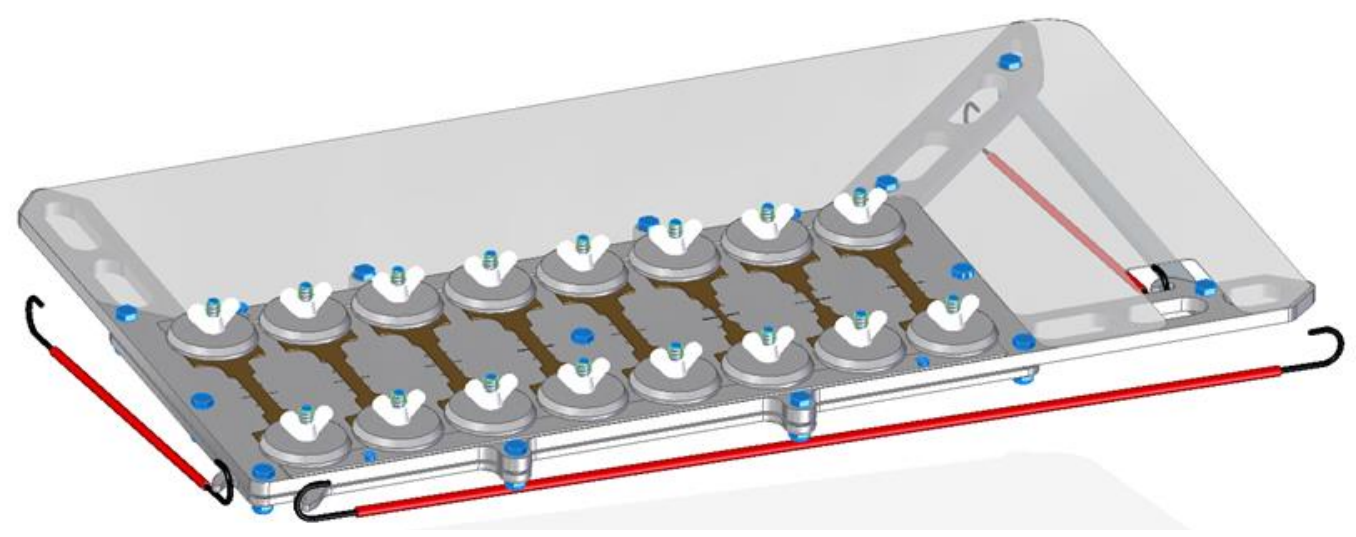

Fig. 3: Visualized fixture with eight test specimens

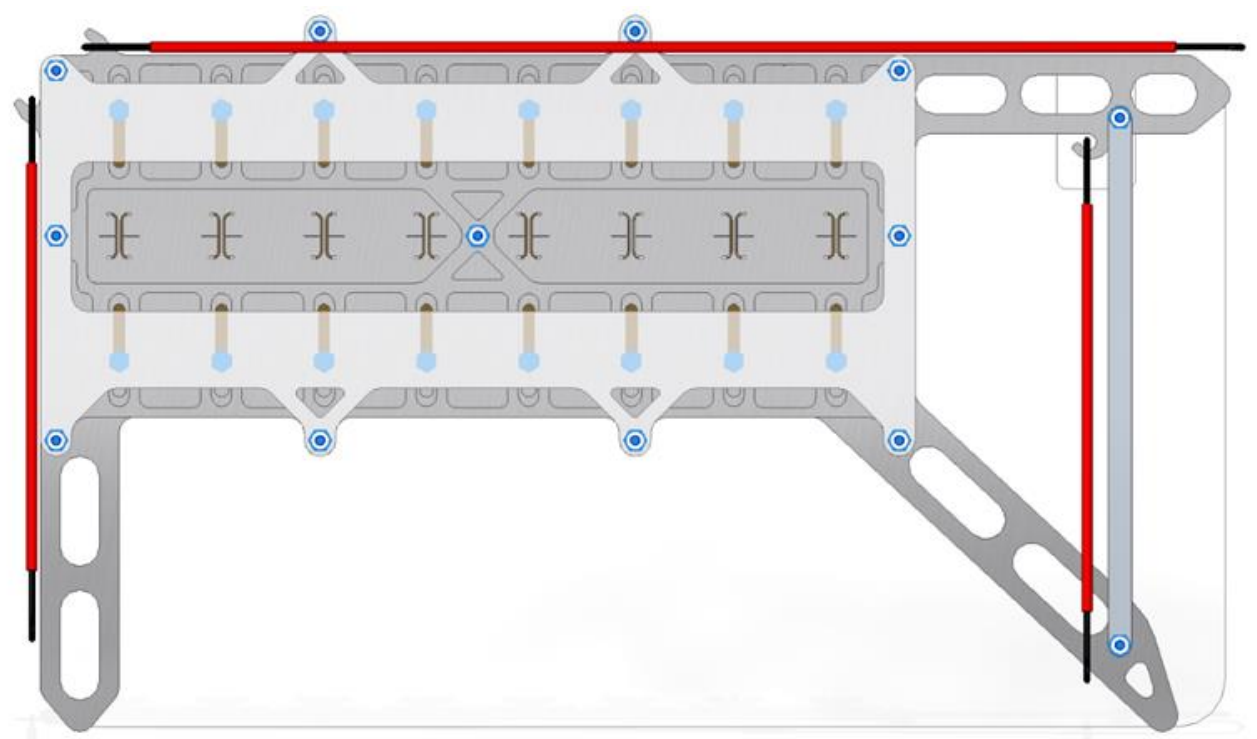

Fig. 4 - Plan view from bottom

The design of the fixture allows up to 8 specimens to be cut out in a single series. This solution is motivated by the economy of and time savings in production. The test specimen is centred in the fixture with V-grooves. Mating cylindrical surfaces are guided accurately in the fixture. At the top, they are provided with threads for holding the specimens in place. The transverse plane of the fixture is provided with marks in the form of channels. These are used for centring the specimens before tightening.

To verify the design and function of the fixture (Fig. 5), it was manufactured of S235 steel. This material is not the optimal choice for this fixture because it lacks corrosion resistance but it is fully sufficient for verifying its function. Semifinished products were also made by waterjet cutting. The fixture was designed to be producible from sheet metal. 


\section{Experimental}

The process was tested in the WJ 2830-2Z-Cobra-PJ60 machine. The experiment compared the alignment of cutouts from the original, and the final shape. A total of 23 specimens were tested (Tab 1). The measurement was carried out using the CMM Carl Zeiss Prismo 7 Navigator 3D measuring machine. A total of four parameters were measured (Fig. 5): specimen width - dimension A, the distance between the right edge of the cutout from the initial contour - dimension $\mathrm{B}$, the distance between the left edge of the cutout and the initial contour - dimension $\mathrm{C}$, and the angle between the centreline of the initial specimen and the centreline of the newly-cut specimen.

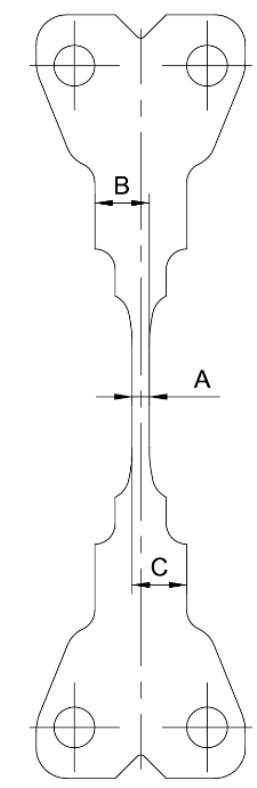

Fig. 5 - Specimen dimensions of interest

Test arrangement:

- $\quad$ PTV JETS 3.8/60-COMPACT high pressure pump (max. operating pressure $415 \mathrm{MPa}$, max. flow $3.81 / \mathrm{min}$ )

- $\quad$ X-Y cutting table PTV WJ 2830-2Z (working space of $3000 \times 2000 \mathrm{~mm}$ )

- Continuously variable cutting speed 0-20 m/min

Experimental conditions

- Operating pressure [MPa]: 400

- Abrasive type: GMA Australian garnet

- Abrasive particle size [MESH]: 200

- Mass flow of abrasive - [g/min]: 30

- Waterjet nozzle diameter [mm]: 0.10

- Abrasive nozzle diameter [mm]: 0.508

- $\quad$ Standoff distance [mm]: 4

Workpiece material

- Material - EN10131 DC01

- Thickness [mm] 1.5

As evidenced by statistical characteristics of the set of results, the fixture meets the requirements for clamping precision (Tab. 1). Since the cutting error is caused by random factors, the two sigma rule can be applied. According to this rule, an interval of two standard deviations around the mean value will contain $95.4 \%$ of the actual measured values according to Gauss distribution. In this case, an accuracy of $+/-0.03 \mathrm{~mm}$ from the mean value is achieved with $95.4 \%$ confidence. As a consequence of inaccurate setting of kerf width compensation, the deviation of the mean width of the test specimen from the required value was $0.15 \mathrm{~mm}$. In a subsequent run, this deviation was eliminated by precise measurement of the first piece and by resetting the kerf width compensation function. The difference of $0.4 \mathrm{~mm}$ between the $\mathrm{B}$ and $\mathrm{C}$ values was due to inaccurate movement to the zero reference point. This error was also eliminated by an improved fixture positioning procedure in the machine. In no case did the misalignment between the initial and the final contour exceed the critical limit of $1^{\circ}$. 


\begin{tabular}{|c|c|c|c|c|}
\hline $\begin{array}{c}\text { Specimen } \\
\text { number }\end{array}$ & $\begin{array}{c}\text { Dimension } \\
\mathbf{A}[\mathbf{m m}]\end{array}$ & $\begin{array}{c}\text { Dimension } \\
\mathbf{B}[\mathbf{m m}]\end{array}$ & $\begin{array}{c}\text { Dimension } \\
\mathbf{C}[\mathbf{m m}]\end{array}$ & Angle $\left[^{\circ}\right]$ \\
\hline 1 & 3.181 & 10.335 & 10.697 & 0.77 \\
\hline 2 & 3.174 & 10.385 & 10.696 & 3.27 \\
\hline 3 & 3.182 & 10.336 & 10.678 & 0.23 \\
\hline 4 & 3.177 & 10.351 & 10.674 & 1.10 \\
\hline 5 & 3.186 & 10.269 & 10.788 & 0.45 \\
\hline 6 & 3.163 & 10.325 & 10.721 & 7.22 \\
\hline 7 & 3.178 & 10.322 & 10.767 & 3.19 \\
\hline 8 & 3.168 & 10.335 & 10.732 & 5.38 \\
\hline 9 & 3.199 & 10.360 & 10.740 & 4.33 \\
\hline 10 & 3.142 & 10.412 & 10.640 & 0.52 \\
\hline 11 & 3.202 & 10.252 & 10.840 & 0.03 \\
\hline 12 & 3.180 & 10.364 & 10.690 & 1.42 \\
\hline 13 & 3.168 & 10.228 & 10.856 & 4.97 \\
\hline 14 & 3.182 & 10.370 & 10.745 & 2.05 \\
\hline 15 & 3.186 & 10.318 & 10.787 & 0.55 \\
\hline 16 & 3.190 & 10.312 & 10.734 & 4.43 \\
\hline 17 & 3.196 & 10.303 & 10.763 & 2.35 \\
\hline 18 & 3.175 & 10.412 & 10.664 & 0.45 \\
\hline 19 & 3.207 & 10.286 & 10.865 & 3.27 \\
\hline 20 & 3.193 & 10.407 & 10.683 & 4.85 \\
\hline 21 & 3.189 & 10.255 & 10.773 & 1.97 \\
\hline 22 & 3.209 & 10.376 & 10.677 & 3.88 \\
\hline 24 & 3.186 & 10.354 & 10.734 & 7.83 \\
\hline Mean value & 3.183 & 10.333 & 10.737 & 2.805 \\
\hline $\begin{array}{l}\text { Standard } \\
\text { deviation }\end{array}$ & 0.015 & & & \\
\hline & & & & \\
\hline
\end{tabular}

Tab 1. - Results of measurement

\section{Conclusion}

As many roads lead to the final destination, each product can be manufactured in various ways. When producing of the product, the goal was to produce the product for cutting tensile tests specimens in such way, which will fullfill not only all reguirements of drawing documentation, but also will be produced in the cheapest way. Another aim was to demonstrate practical experience of making the product with the technology of waterjet cutting.

Waterjet cutting was used for making a fixture for preparing test specimens for tensile testing. As the materials in question were AHSS steels, the specimens were impossible to be prepared in required quality, quantity and at the required cost by classical machining routes. The fixture for making eight test specimens was tested. It was found that all requirements for the test specimen quality have been met.

In the future, we will focus on optimizing cutting conditions and their influence on surface integrity.

\section{Acknowledgements}

The present contribution has been prepared under the project LO1502 'Development of the Regional Technological Institute under the auspices of the National Sustainability Programme I of the Ministry of Education of the Czech Republic aimed to support research, experimental development and innovation.

\section{References}

[1] http://www.esabna.com/us/en/education/blog/what-is-the-best-way-to-cut-steel-plate.cfm, (2013). What Is The Best Way To Cut Steel Plate, ESAB KNOWLEDGE CENTER, Accessed on: 2016-08-12

[2] Kašpar J. (2011). Thermal oxidative cutting, Tepelné dělení materiálu kyslíkem, MM Průmyslové spectrum, Vol. 2011, No. 24, pp 25, ISSN: 1212-2572

[3] Roubíček M., (2016). Criteria for the choice of method and trends in materials thermal cutting. Kriteria volby metody a trendy tepelného dělení materiálu, Available from: http://www.airliquide.cz/file/otherelement/pj/roubicek49122.pdf, Accessed: 2016-08-10 
[4] http://www.flowwaterjet.com/Resources/Ask-Dr-Hashish-a-Question, (2016). Ask Dr. Hashish - Dr. Mohamed Hashish is the inventor of the abrasive waterjet and an expert in high pressure design and tribology., Accessed on: 2016-08-12

[5] Zeman Z. (2013). What is the secret of electrocorrosion. V čem spočívá tajemství elektroeroze, Technický týdeník, Vol. 2013, No. 24, pp 25, ISSN: 0040-1064

[6] Dvoráková, J.; Dvorák, J. (2007). Milling and Engraving With Unconventional Technology AWJ, Frézování a gravírování nekonvenční technologií AWJ, MM Průmyslové spectrum, Vol. 2007, No. 4, pp 56, ISSN: $1212-$ 2572

[7] Vorel, I., Vancura, F., Pilecek, V., Jirkova, H., Masek, B. (2015). Material-technological Modelling of C45 Steel die Forgings. In 25th DAAAM International Symposium Intelligent Manufacturing \& Automation -2014, Vienna, ISSN: 1877-7058, Katalinic, B. (Ed.), pp. 714-721, Published by Elsevier Ltd, doi:10.1016/j.proeng.2015.01.424

[8] Martinec, P.; Sitek, L. (2015). Abrasives and possibilities of increase in efficiency of abrasive waterjets. In: Vodní paprsek 2015 - výzkum, vývoj, aplikace, Sitek, L., Klichová, D. (Ed.), pp 157-163, Ústav geoniky AV ČR, ISBN 978-80-86407-56-2, Ostrava

[9] Radocovic M. (2007) Abrasive waterjet cutting. Modelling And Optimization In The Machines Building Field. Volume III , No. 13, 2007, ISSN 1224-7480

[10] Aišman, D., Staňková, H., Skálová , L., Mašek, B. (2008). Testing of the parameters of the Q-P process in high strength low-alloyed steel. In Danube Adria Association for Automation and Manufacturing. Vienna Austria: DAAAM International, Vienna Austria, 2008. ISBN: 978-3-901509-68-1, Vienna, Austria

[11] Kana, J; Vorel, I \& Ronesova, A. (2016). Simulator of Thermomechanical Treatment of Metals, Proceedings of the 26th DAAAM International Symposium, pp.0513-0518, B.Katalinic (Ed.), Published by DAAAM International, ISBN 978-3-902734-07-5, ISSN 1726-9679, Vienna, Austria 